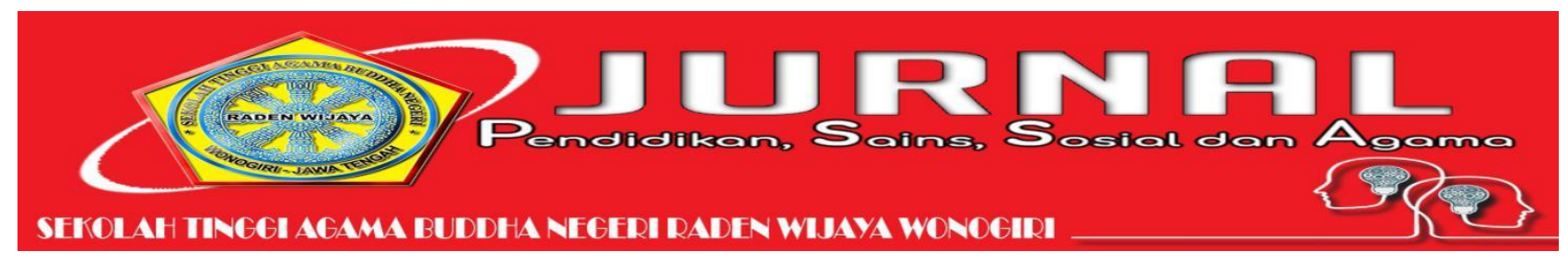

\title{
ANALISIS KEBIJAKAN PENGEMBANGAN PENDIDIKAN (PERGURUAN TINGGI) DI INDONESIA
}

\author{
Kabul Praptiyono \\ SEKOLAH TINGGI AGAMA BUDDHA MAHA PRAJNA JAKARTA \\ kabulmetta@gmail.com
}

\begin{abstract}
ABSTRAK
Penelitian ini bertujuan untuk mengetahui analisis kebijkaan pengembangan pendidikan perguruan tinggi di Indonesia, Penelitian ini menggunakan pendekatan kualitatif deskriptif, dimana subyek penelitian adalah kebijakan pemerintah terkait dengan pengembangan pendidikan perguruan tinggi Pengumpulan data dalam penelitian ini menggunakan dokumentasi, dan observasi. Teknik analisis data menggunakan model Miles and Huberman. Hasil penelitian diketahui bahwa Pendidikan adalah Suatu usaha untuk mewujudkan suatu suasana pembelajaran dan pengembangan diri baik secara fisik maupun non fisik yang dapat diterapkan dikehidupan berkeluarga, bermasyarakat ,berbangsa dan bernegara, Perkembangan teknologi dan informasi menyebabkan peranan perguruan tinggi sebagai lembaga pendidikan akan mejadi lebih tinggi. Peruruan tinggi tidak lagi menjadi satu-satunya pusat pembelajaran karena aktivitas belajar tidak lagi terbatasi oleh ruang dan waktu. Peran dosen tidak akan menjadi satu-satunya sumber belajar karena banyak sumber belajar dan informasi yang mampu memfasilitasi orang untuk belajar. Oleh karena itu aktualisasi partisipasi masyarakat dalam pengembangan pendidikan sangat diperlukan.
\end{abstract}

Kata Kunci: Kebijkan Pengembangan, Pendidikan Perguruan Tinggi

\section{ABSTRACT}

This research aims to find out the policy analysis of the development of higher education in Indonesia, this research uses a descriptive qualitative approach, where the subject of research is government policy related to the development of higher education Data collection in this research using documentation, and observation. Data analysis techniques using miles and huberman models. The results of the study is known that Education is an effort to realize an atmosphere of learning and self-development both physically and non-physical that can be applied in the life of a family, society, nation and state, the development of technology and information causes the role of universities as educational institutions will be higher. High peruruan is no longer the only learning center because learning activities are no longer limited by space and time. The role of lecturers will not be the only source of learning because many learning resources and information are able to facilitate people to learn. Therefore, the actualization of community participation in the development of education is indispensable.

Keywords: Development Policy, Higher Education 


\section{PENDAHULUAN}

Secara singkat pendidikan merupakan produk dari masyarakat. Pendidikan tidak lain merupakan proses tranmisi pengetahuan, sikap, kepercayaan, ketrampilan dan aspek perilaku-perilaku lainnya kepada generasi kegenerasi. Dengan pengertian tersebut, sebenarnya upaya diatas sudah dilakukan sepenuhnya oleh kekuatan-kekuatan masyarakat. Hampir segala sesuatu yang kita pelajari adalah hasil dari hubungan kita dengan orang lain, baik dirumah, sekolah, tempat bermain, pekerjaan dan lainnya. Dengan kata lain di manapun kita berada kita pasti akan belajar dan mendapatkan ilmu pengetahuan. Bagi suatu masyarakat, hakikat pendidikan diharapkan mampu berfungsi menunjang kelangsungan kemajuan hidupnya, agar masyarakat dapat melanjutkan eksistensinya, maka diteruskan nilai-nilai, pengetahuan, ketrampilan dan bentuk tata perilaku lainnya bagi generasi muda. Tiap masyarakat selalu berupaya meneruskan kebudayaannya dengan proses adaptasi tertentu sesuai coraknya masing-masing periode zamannya kepada generasi muda melalui pendidikan atau secara khusu melalui interaksi sosial. Dengan demikian fungsi pendidikan tidak lain adalah sebagai proses sosialisai (Nasution: 1999).

Pengembangan pendidikan di Indonesia harus menyesuaikan dengan kebutuhan masyarakat sebagai pengguna pada saat ini. Mengenai kebijakan ada beberapa standart yang harus terpenuhi diantaranya adalah Asosiasi Dosen \& Unit Penelitian dan Pengabdian Masyarakat
Standar Biaya Minimum Pendidikan, Kebijakan, Anggaran, dan Mutu Pendidikan. Perguruan tinggi berfungsi sebagai organisasi penyedia layanan proses belajar-mengajar yang keberadaannya tidak dapat dipisahkan dari masyarakat. Pendidikan tinggi sebagai proses dekonstruksi masyarakat manusia dengan sisi kehidupan yang kompleks dan terkait satu sama lain, yaitu keagamaan, seni dan budaya, sosial, ekonomi, dan politik. Di sisi lain, sebagai individu, kebutuhan antara satu manusia dan yang lainnya berbeda-beda. Variabilitas kebutuhan individu tersebut berimplikasi pada variabilitas kebutuhan layanan pendidikan, seperti layanan peserta didik yang ingin langsung masuk pasar kerja dan siap masuk dunia kerja dengan adanya hal ini maka perguruan tinggi harus mampu membantu peserta didik mengembangkan potensinya, baik sebagai makhluk sosial maupun sebagai individu.

Sebagai makhluk sosial, peserta didik harus belajar mengenal dan mengikuti norma dan pranata kehidupan yang berlaku. pendidikan memiliki dimensi ganda, yaitu teknis dan pembangunan, dimensi teknis pendidikan berkaitan dengan layanan para individu mahasiswa, seperti layanan mahasiswa cerdas, mahasiswa luar biasa yang berkebutuhan khusus, dan mahasiswa yang memerlukan keterampilan untuk masuk dunia kerja. Dimensi pengembangan berkaitan dengan peningkatan kehidupan sosial masyarakat, seperti terbentuknya masyarakat 
yang makmur dan sejahtera. Pendidikan diselenggarakan secara demokratis daan berkeadilan serta tidak diskriminatif dengan menjunjung tinggi hak-hak asasi manusiaa, nilai kultural, dan kemajemukan bangsa. Kualitas pendidikan Sementara itu, untuk meningkatkan kualitas pendidikan Indonesia perlu berkaca pada Negara lain. Contohnya negara tetangga yaitu Malaysia, di Negara Malaysia walaupun dengan kesederhanaan di sana tetap mampu mewujudkan pendidikan yang berkualitas baik.

\section{METODE}

Penelitian ini menggunakan metode penelitian deskriptif kualitatif karena kajian ini bertujuan untuk memperoleh pengetahuan yang lebih komprehensif dengan mendasarkan terkait

Analisis Kebijakan Pengembangan Pendidikan Perguruan Tinggi di Indonesia. Sugiyono (2013: 25) mengemukakakn bahwa phenological research adalah salah satu jenis penelitian kualitatif, dimana peneliti melakukan pengumpulan data dengan observasi untuk mengetahui fenomena esensial pertisipan dalam pengalaman. Objek dan Subjek Kajian Analisis Kebijakan Pengembangan Pendidikan Perguruan Tinggi di Indonesia. Subjek kajian difokuskan pada masyarakat guna menyikapi pengembangan pendidikan tinggi. Sumber data dalam kajian ini terdiri atas dua sumber, antara lain sumber primer dan sumber sekunder. Sumber primer yang digunakan Kemenristek dan Tehknologi/
Badan Riset dan Inovasi Nasional, Sedangkan sumber sekunder yang digunakan adalah berupa jurnal, annual report, Buku, dari internet serta literatur mengenai Analisis Kebijakan Pengembangan Pendidikan Perguruan Tinggi di Indonesia. Metode yang digunakan untuk mengumpulkan data dalam penelitian ini adalah studi pustaka. Studi pustaka lebih difokuskan pada pencarian data dan informasi melalui dokumen berupa jurnal, berita, teks, buku-buku.

Analisis data kualitatif yang dipergunakan dalam penelitian ini dilakukan dengan menggunakan alur kegiatan seperti yang dikemukakan oleh Miles \& Huberman (1984: 21) yakni data collection, data reduction, data display, and data conclution (drawing/verifying). Data collection dilakukan pengumpulan data hasil observasi, dan berbagai dokumen berdasarkan kategorisasi yang sesuai dengan masalah penelitian yang kemudian dikembangkan penajaman data melalui pencarian data selanjutnya. Data Reduction analisis menajamkan, menggolongkan, mengarahkan, membuang data yang tidak perlu, dan mengorganisasi data dengan cara sedemikian rupa sehingga simpulan final dapat ditarik, dan diverifikasi. Data Display rangkaian organisasi informasi yang memungkinkan kesimpulan riset dapat dilakukan, dilakukan untuk menemukan pola-pola yang bermakna serta memberikan kemungkinan adanya penarikan simpulan serta memberikan 
tindakan. Data Conclution merupakan penarikan kesimpulan kesatuan dari bagian kegiatan konfigurasi yang utuh.

\section{HASIL DAN PEMBAHASAN}

Arah pengembangan kebijakan pendidikan tinggi Indonesia beberapa tahun mendatang dilatarbelakangi oleh hadirnya globalisasi (MEA 2016), dengan implikasi berupa kebutuhan peningkatan kemampuan berkompetisi bangsa Indonesia dalam masyarakat dunia yang semakin berbasis pengetahuan (Knowledge Based Society). Pendidikan tinggi harus mampu menghasilkan dua hal penting untuk menghadapi itu:

1) Insan berkarakter dan kreatif yang berbasis pada penguasaan ilmu pengetahuan.

2) Inovasi teknologi melalui konvergensi berbagai cabang keilmuan.

Inovasi dalam arti teknologi yang telah diwujudkan dalam bentuk kegiatan industri yang menciptakan lapangan kerja sehingga berdampak langsung pada peningkatan kesejahteraan rakyat. Kedua hal ini mustahil diwujudkan tanpa pembangunan budaya mutu di perguruan tinggi. Mutu sendiri secara umum didefinisikan sebagai pemenuhan tuntutan standar; sesuatu disebut bermutu apabila memenuhi standar. Di era yang semakin kompetitif ini, keberlanjutan akan sangat ditentukan oleh mutu. Hal ini juga berlaku bagi perguruan tinggi. Cepat atau lambat perguruan tinggi yang tidak bermutu akan mati karena ditinggalkan oleh masyarakat sebagai pengguna jasa pendidikannya. Daya beli masyarakat akan terus meningkat dengan semakin menguatnya ekonomi bangsa dan masyarakat juga akan semakin cerdas dalam menilai suatu perguruan tinggi. Kehadiran perguruan tinggi kelas dunia di Indonesia hanya soal waktu saja dan hal ini merupakan suatu tantangan tersendiri bagi perguruan tinggi yang sudah ada di Indonesia dengan hadirnya mereka maka merupakan suatu tantangan dan saingan bagi perguruan tinggi sehingan waktu bagi perguruan tinggi Indonesia semakin sempit untuk mempersiapkan diri menghadapi kompetisi memperebutkan pangsa pasar. Berbagai kebijakan pendidikan tinggi Indonesia di antaranya adalah untuk mendorong peningkatan mutu perguruan tinggi. Kehadiran Standar Nasional Pendidikan Tinggi dimaksudkan untuk hal tersebut. Setiap perguruan tinggi di Indonesia terikat untuk memenuhi standar ini yang sesungguhnya pemenuhannya merupakan mutu minimum yang harus dimiliki oleh setiap perguruan tinggi di Indonesia. Standar ini mempunyai dua fungsi penting, pertama menjadi acuan mutu minimum dan kedua menjadi penangkal masuknya Perguruan Tinggi asing abal-abal. Oleh karena itu betapapun 
sulitnya untuk dipenuhi namun standar ini tidak mungkin diturunkan.

Dalam hal ini dalam rangka mengikuti perkembangan pendidikan tinggi untuk mencetak Insan berkarakter dan kreatif yang berbasis pada penguasaan ilmu pengetahuan ini menjadi tanggung jawab seorang dosen tidaklah mudah, selain sebagai agen untuk terjadinya transfer of knowlwdge (pengetahuan), transfer of skills (keterampilan), sekaligus juga agen untuk terlaksananya transfer of experience (pengalaman) dan yang lebih berat lagi adalah transfer of value (nilai). Pada dua bagian terakhir secara nyata haruslah menjadi contoh yang nyata untuk memberikan pengalaman belajar dan sekaligus menyampaikan pesanpesan moral yang berupa nilai-nilai karakter budaya bangsa. Dalam kajian manajemen, sosok dosen yang ideal setidaknya memenuhi tiga kriteria, yaitu pertama visioner, punya imajinasi, dan wawasan jauh ke depan dalam mengemban tugasnya di tengah perubahan dan persaingan global yang sulit diprediksi. Kedua, memiliki keterampilan manajemen (managerial skill) guna memimpin proses perubahan dalam pendidikan yang diberikan yang tertuang dalam program nyata. Ketiga, mereka harus memiliki integritas kuat, sesuai antara ucapan dan tindakan (walk the talk) sehingga menjadi panutan bagi para mahasiwanya.

(Komarudin Hidayat, 2004). Tugas seorang dosen saat ini yang mendidik peserta didiknya dalam kondisi melemahnya moralitas dan karakter budaya bangsa tentulah menjadi lebih berat. Karena pada dasarnya pendidikan harus dilakukan secara terpadu yang merupakan upaya sadar, terstruktur, terprogram, dan sistematis yang bertujuan untuk membentuk manusia yang memiliki karekter budaya bangsa. Dalam sebuah system pembelajaran, peranan seorang dosen sangatlah menentukan. Metode atau cara pembelajaran lebih penting daripada materi pembelajaran dan dosen lebih penting dari segalanya, ungkapan ini mengandung makna bahwa seorang dosen harus menguasai materi pembelajaran yang akan disampaikan. Lebih baik dari itu, penguasaan metode pembelajaran oleh seorang dosen memiliki arti lebih penting lagi dan menentukan keberhasilan suatu proses pembelajaran daripada hanya penguasaan materi. Di atas itu semua, posisi dan peran dosen jauh lebih penting dan menentukan atas segalanya. Materi, metode, media, dan sumber pembelajaran, semuanya menjadi tidak bermakna apabila dosen tidak mampu memerankan tugasnya dengan baik. dosen merupakan ujung tombak sekaligus dirigen yang berperan memimpin pertunjukan orkestra pembelajaran. Oleh karena itu pula, pembinaan dan mempersiapkan calon dosen yang profesional melalui berbagai pelatihan dan studi lanjutan sangat penting dan strategis. Dalam konteks ini, seorang mahaguru pernah bertutur, jadilah guru atau 
dosen atau tidak sama sekali. Jadilah dosen dengan berbekal kompetensi dan profesi sebagai dosen, bila tidak, lebih baik tidak sama sekali. Peran dan profesi dosen bukanlah permainan. Setiap orang bisa menjadi atau menempati posisi sebagai pendidik. Orang tua, disadari ataupun tidak, adalah pendidik bagi anak-anaknya. Setiap dosen adalah pendidik, tetapi tidak setiap pendidik adalah guru atau dosen. Apa perbedaannya mengenai hal ini dosen adalah pendidik professional, dosen merupakan salah satu faktor penentu tinggi rendahnya mutu hasil pendidikan. Keberhasilan penyelenggaraan pendidikan sangat ditentukan oleh sejauh mana kesiapan dosen dalam mempersiapkan peserta didiknya melalui kegiatan belajar-mengajar. Namun demikian, posisi strategis dosen untuk meningkatkan mutu hasil pendidikan sangat dipengaruhi oleh kemampuan kompetensi profesional mengajarnya. Kompetensi adalah kemampuan, kecakapan, keadaan berwenang, atau memenuhui syarat menurut ketentuan hukum. Kompetensi dosen adalah kemampuan seorang dosen dalam melaksanakan kewajiban-kewajibannya secara bertanggung jawab dan layak. Jadi kompetensi profesional dosen dapat diartikan sebagai kemampuan dan kewenangan dosen dalam menjalankan profesi kedosenannya.

Mengacu kepada uraian di atas, maka kompetensi profesional dosen dapat diartikan sebagai kemampuan seorang dosen dalam melaksanakan tugas profesi keguruan dengan penuh tanggung jawab dan dedikasi tinggi dengan sarana penunjang berupa bekal pengetahuan yang dimilikinya. Kompetensi merupakan perilaku yang irasional untuk mencapai tujuan yang dipersyaratkan sesuai dengan kondisi yang dipersyaratkan pula. Kompetensi sangat diperlukan untuk mengembangkan kualitas dan aktivitas tenaga kependidikan. Dosen sebagai pendidik ataupun sebagai pengajar merupakan faktor penentu keberhasilan pendidikan di pergrauan tinggi. Tugas dosen yang utama adalah memberikan pengetahuan (cognitive), sikap/nilai (affective), dan keterampilan (psychomotor) kepada para mahasiwanya. Tugas dosen di lapangan berperanan juga sebagai pembimbing proses belajar mengajar untuk mencapai tujuan pendidikan tinggi. Dengan demikian tugas dan peranan dosen adalah sangat krusial dalam menghasilkan lulusan yang berkarakter dan kreatif yang berbasis pada penguasaan ilmu pengetahuan, disamping dengan harus adaperan dari pergurun tinggi dalam mengahadapi kebijakan ini karena bagi perguruan tinggi sudah seharusnya mendudukung hal ini dengan menyidiakan sarana dan prasana dalam kegiatan pembelajaran supaya bisa tercapai tujuan dari kegiatan pembelajaran di perguruan tinggi. Serta perguruan tinggi harus memiliki inovasi dalam rangka mendudukung inovai yang dikeluarkan oleh pemerintah. 
Inovasi adalah suatu gagasan, teknik-teknik atau benda yang disadari dan diterima oleh seseorang atau kelompok untuk diadopsi. Inovasi sebagai sesuatu gagasan atau ide baru yang diterapkan untuk membuat atau mengembangkan sebuah produk, proses atau jasa.

Perkembangan teknologi dan informasi menyebabkan peranan perguruan tinggi sebagai lembaga pendidikan akan menjadi lebih tinggi. Namun dengan berkembangnya ilmu pengetahuan Peran dosen tidak akan menjadi satu-satunya sumber belajar karena banyak sumber belajar dan informasi yang mampu memfasilitasi orang untuk belajar. Oleh karena itu aktualisasi partisipasi masyarakat dalam pengembangan pendidikan sangat diperlukan. Pendidikan adalah Suatu usaha untuk mewujudkan suatu suasana pembelajaran dan pengembangan diri baik secara fisik maupun non fisik yang dapat diterapkan dikehidupan berkeluarga,bermasyarakat,berbangsa dan bernegara. Ada dua faktor yang mempengaruhi kualitas pendidikan khususnya di Indonesia yaitu: Faktor internal, meliputi jajaran dunia pendidikan baik itu Departemen Pendidikan Nasional, Dinas Pendidikan Daerah, dan juga sekolah yang berada di garis depan.Dalam hal ini,interfensi dari pihakpihak yang terkait sangatlah dibutuhkan agar pendidikan senantiasa selalu terjaga dengan baik. Faktor eksternal, adalah masyarakat pada umumnya. Dimana, masyarakat merupakan ikon pendidikan dan merupakan tujuan dari adanya pendidikan yaitu sebagai objek dari pendidikan. Berbicara tentang pendidikan di Indonesia seolah tidak mengenal kata selesai. Disebabkan oleh Pertama, pesimisnya masyarakat atas kebijakan pemerintah. Kedua, terlalu bersemangatnya pemerintah untuk mengikuti cepatnya perkembangan pendidikan di belahan lain dunia ini. Bisa jadi pemerintah iri dengan gemerlapnya sistem pendidikan di negeri-negeri lain.

Polemik pendidikan di Indonesia selama ini berkutat pada persoalan dana, pengadaan infrastruktur, dan kurikulum bongkar pasang. Seharusnya perdebatan ini tak perlu dilakukan. Sebabnya sederhana saja, bahwa pengadaan ketiga hal itu mutlak menjadi tanggung jawab pemerintah. Tentu jika memang membutuhkan masukan dari pihak lain, misalnya pengusaha, pakar pendidikan, atau perwakilan masyarakat, hal itu sangat dimungkinkan. Dalam hal ini, ada dua hal yang menjadi kunci solusi yakni konsistensi, dan komitmen. Konsistensi dalam hal penerapan kurikulum dan kebijakan terkait lainnya. Harus ada pembicaraan antara pembuat kebijakan dengan penyelenggara industri atau pihak pemakai produk pendidikan yakni para lulusan, dalam penyusunan kurikulum. Dengan demikian dua dunia tersebut akan terhubungkan oleh jembatan bernama kurikulum pendidikan. Dua dunia tersebut tidak lagi menjadi menara 
gading ditempatnya. Komitmen dibutuhkan

oleh semua pihak. Bahwa semua aspek turut bertanggung jawab pelaksanaan pendidikan di negeri ini. Pun dalam hal ini generasi muda. Meminjam istilah sahabat saya, generasi muda tidak boleh terus-menerus memposisikan diri sebagai korban. Saatnya semua pihak bergerak di tempat dan bidangnya masing-masing.

Bentuk aktualisasi dan pernyataan penyadaran diri masyarakat secara kolektif dapat berupa partisipasinya dalam proses pengambilan keputusan yang berhubungan dengan kebutuhan dirinya dan kelompoknya dalam komunitas yang melingkupinya. Caracara kolektif berpartisipasi dalam bermasyarakat bisa teraktualisasikan dalam bentuk musyawarah dan juga terbentuknya institusi lokal oleh masyarakat itu sendiri. Musyawarah adalah sebuah pendekatan kultural khas Indonesia yang dapat dimasukkan dalam proses ekplorasi kebutuhan dan identifikasi masalah. Musyawarah juga merupakan bentuk sarana untuk meningkatkan rasa partisipasi dan rasa memiliki atas keputusan dan rencana pembangunan. Musyawarah dapat merupakan cara analisis kebutuhan dan tidak sekedar keinginan yang bersifat superfisial demi pemenuhan kebutuhan sesaat. Oleh karena itu pemilihan orang-orang yang mewakili sebagai peserta musyawarah untuk suatu keperluan seperti merumuskan kebutuhan masyarakat haruslah benar-benar yang mampu menyalurkan aspirasi masyarakat yang diwakilinya. Lepas dari banyaknya kelebihan pendidikan tinggi di Indonesia, terdapat juga beberapa kekurangan yang perlu dibenahi. Hal ini mungkin disebabkan oleh program dan kebijakan pendidikan tinggi yang masih perlu di benahi. Adapun kekurangan yang mungkin perlu diperhatikan dan dibenahi secara umum adalah Pertama mengenai pelayanan jasa pendidikan tinggi baru dinikmati oleh mayoritas kalangan keluarga kelas menengah keatas atau hanya segelintir kalangan kelas menegah kebawah yang dapat menikmati jasa pendidikan tinggi. Idealnya, pelayanan jasa pendidikan tinggi tidak menciptakan dikotomi dan disparitas terutama berakaitan dengan akses rekrutmen mahasiswa baru.

\section{KESIMPULAN}

Pendidikan adalah Suatu usaha untuk mewujudkan suatu suasana pembelajaran dan pengembangan diri baik secara fisik maupun non fisik yang dapat diterapkan dikehidupan berkeluarga, bermasyarakat ,berbangsa dan bernegara, Perkembangan teknologi dan informasi menyebabkan peranan perguruan tinggi sebagai lembaga pendidikan akan mejadi lebih tinggi. Peruruan tinggi tidak lagi menjadi satu-satunya pusat pembelajaran karena aktivitas belajar tidak lagi terbatasi oleh ruang dan waktu. Peran dosen tidak akan menjadi satu-satunya sumber belajar karena banyak sumber belajar dan informasi yang mampu memfasilitasi orang untuk belajar. 
Oleh karena itu aktualisasi partisipasi masyarakat dalam pengembangan pendidikan sangat diperlukan.

\section{REFERENSI}

Abdul, Wahab Solichin 2004. Analisis Kebijakan dari Formulasi ke Implementasi Kebijaksanaan Negara. Jakarta: Bumi Aksara

Benny Heldrianto, 2013: dalam jurnal "Penyebab Rendahnya Tingkat Pendidikan Anak Putus Sekolah Dalam Program Wajib Belajar 9 Tahun Desa Sungai Kakap Kecamatan Sungai Kakap Kabupaten Kubu Raya" http://jurmafis.untan.ac.id

Bauer, Raymond A, 2013. Pengantar Analisi Kebijakan Publik. Bauer, Raymond A, 2013. Pengantar Analisi Kebijakan Publik.

Dun, William N, 2013. Pengantar Analisi Kebijakan Publik. Yogyakarta: Gajah Mada University Press.

George A. Steiner dan John B. Miner, Management Policy and Strategy, Alih Bahasa Ticoalu dan Agus Dharma, Kebijakan dan Strategi Manajemen, edisi Kedua, Erlangga, Jakarta, 1997, hlm. 22

Haryanto, 2012: dalam artikel "Pengertian Pendidikan" menurut para akhli http://belajarpsikologi.

com/pengertianpendidikan-menurutahli/ diakes pada tanggal 9 april 2017

https://edukasi.kompas.com/read/2011/12/16/

09353211/Pengembangan.Pendidikan.H arus.Sesuai.Kebutuhan

http://steeam.blogspot.com/2009/01/perkemb

angan-pendidikan-di-indonesia.html

Hidayat, Komarudin, 2004. Pengembangan

Kurikulum Baru. Bandung: PT Remaja

http://meilanikasim.wordpress.com/2009/03/0

8/makalah-masalah-pendidikan-di-indonesi http://www.kumpulandefinisi.com/2015/10/pe ngertian-definisi-tujuan-pendidikanmenurut-para-ahli.html

http://eprints.umm.ac.id/41375/3/BAB\%20II. pdf

http://staffnew.uny.ac.id/upload/132058092/la inlain/makalah-ppsb-man-3.pdf https://www.kompasiana.com/nurul85230/5ea bda38d541df431b0b1d72/apakah-model kelompok-bermain-individu-dapatmeningkatkan-kemampuanpemahaman-konsep-matematis-siswapada-materi-bangun-datar-danmenumbuhkan-minat-belajar-sisw

https://r.search.yahoo.com/_ylt=Awr9CKrW3 Qhg0AYABH1XNyoA;_ylu=Y29sbwN ncTEEcG9zAzEEdnRpZANBMDU5O V8xBHNIYwNzcg/RV=2/RE=1611222 614/RO=10/RU=https\%3a\%2f\%2fseput arilmu.com\%2f2020\%2f09\%2fpengertia n-pendidikan-menurut-paraahli.html/RK=2/RS=jVdAcXeEL9LIFit 0UhZm1rHot9Q-

https://tokoh.co.id/biografi-ki-hajardewantara-bapak-pendidikan-indonesia/ Kebijakan Kemristekdikti Terkait Pendidikan Tinggi Dan Pendidikan Profesi Insinyur: 4 Oktober 2017, Kementerian Riset, Teknologi, dan Pendidikan Tinggi. http://k8bksti.ub.ac.id/wpcontent/uploads/2017/03/BKSTI-

Sarasehan-Dirjen.pdf

Muslah, Jejen, 2018. Analisis Kebijakan Pendidikan. Jakarta: CV Jaya Abadi

Miles, M. B., \& Huberman, A. M. 1984. Qualitative Data Analysis. London: Sage

Nasution, Buyung, 1999. Filsafat dan Mistisisme Dalam Islam. Jakarta: Bulan Bintang

Notoatmodjo, Soekidjo, 2003. Pendidikan dan Perilaku Kesehatan. Jakarta: Rineka Cipta.

Puslitjak Balitbang Kementerian Pendidikan dan Kebudayaan di Bogor, Jawa Barat, Jumat (16/12/2011). 
Jurnal Pendidikan, Sains Sosial dan Agama Volume 7 Nomor 1

Sugiyono. 2013. Metode Penelitian Kualitaif Kuantitatif dan $R \& D . \quad$ Bandung: Alfabeta.

Tim Penyusun Kamus Pusat Bahasa, 2002. Kamus Besar Bahasa Indonesia, Jakarta: Balai Pustaka

Yusrin Ahmad Tosepu, Periset Pada Lembaga Studi Pengkajian dan Pengembangan Pendidikan Tinggi Indonesia (LSP3I) Pusat Makassar. Ketua Lembaga Kajian Data dan Informasi Digital KAVITA MEDIA Penggiat Literasi Media ICT (Information and Communication Technology).

Undang-Undang Nomor 20 Tahun 2004

Tentang SISDIKNAS

Undang-Undang Nomor. 12 Tahun 2012 Tentang Pendidikan Tinggi 